Nadiia Yasynska, D.Sc. (Economics), Associate Professor, Professor of the Department of Finance, Accounting and Taxation, Donetsk State University of Management (Mariupol, Ukraine)

Olena Tarasenko, Ph.D. (Economics), Associate Professor of the Department of Finance, Accounting and Taxation, Donetsk State University of Management (Mariupol, Ukraine)

Olena Tanchyk, Ph.D. (Economics), Head of the Department of Foreign Languages, Donetsk State University of Management (Mariupol, Ukraine)

\title{
ECONOMIC CENTRISM OF BUSINESS ENTITIES IN MODERN FINANCIAL DEVELOPMENT
}

\begin{abstract}
The aim of the article is to identify the characteristics and specifics of economic centrism of economic entities in modern financial development. The hypothesis of research that central planning is not possible for market development, and on the other hand, the diversity and adaptability of human behaviour in the economic sphere is the most significant circumstance of computational complexity that exceeds human or machine properties in search of an optimal solution. The research analyses the problem development through the time with highlighting main ideas, pros and cons, threats and opportunities. The paper states that the current financial and economic development of modern local economies of the world. It is impossible to expect that increasing the capacity of international markets in the near future will allow loading them at the expense of own demand for productive forces. This requires that the productive forces and demand of the population has to reach the level that is capable of restoring working capital in the volumes of full loading of fixed capital with a unified distribution and redistribution of the by-product. The main conclusions focus on statement that further economic development, the finances of economic entities, as generators and recipients of an additional product, take a leading position in initiating and introducing new principles of socio-economic coexistence within the state and the financial system.
\end{abstract}

Keywords: economic development, financial development, finance, capital, world trade, market mechanism, economic entities

Problem statement in general. It is scientifically recognized that economic, including financial as its part, development has two defining forms of stimulation - state and market 
mechanisms. The state one is elaborated with innovative trends of internal and external influence in accordance with the formal characteristics and socio-economic priorities of the entities that form the state. The market mechanism, in contrast, because of the absence of geographical and uniformly written formal rules, has a sufficiently broad but relatively successful practice of economic and financial instruments of appliance and development: any formation as a different system of social relations over time proves to be imperfect in forms, features, rules and principles of existence; the success of production in each system is accompanied by the intensification of trading operations, qualitative and (or) quantitative expansion of markets. Currently, the production process in each country and the supplies of the entire population depend on the proper conduct of trade (optimal balance of supply and demand). This condition is one of the reasons for the influence of local and regional cataclysms of unnatural origin on the economic state and the prospect of a particular country development opposed to the previous historical periods of economic evolution. Accordingly, a significant counterweight to the previous economic systems of public relations was the financial analogue within a market economy. In the context of a prolonged systemic crisis, its success becomes relevant and is the subject of separate scientific research.

Analysis of recent research and publications. Materials of scientific researches of modern experts in the fields of finance and management $[5,6,9]$ specify the trend continuation of net financial results prevailing from analogues in the real sector of the economy in the current economic activity of the world and Ukraine. This is due to the digitalization and intellectualization of business processes, the transition to the Internet sales, the unification of consumer policy etc. Therefore, the principles of state and market mechanisms functioning are changing. In this case, the system of public administration creates a greater amount of new standards and rules of financial and economic actions as a result of the sustainable existence of practice within the market mechanism. Thus, there is an objective need to determine the depth of economic centrism of economic entities as a fact of financial, economic and technical and technological evolution of state and market mechanisms. As stated in [4], on the one hand, central planning is not possible for market development, and on the other hand, the diversity and adaptability of human behaviour in the economic sphere is the most significant circumstance of computational complexity that exceeds human or machine properties in search of an optimal solution.

The purpose of the article is to identify the characteristics and specifics of economic centrism of economic entities in modern financial development. 
Outline of the main research material. The scientific views of modern experts in the field of financial theory and practice differ in regard to the conceptualization of the defining element of the country financial system: some scholars and practitioners consider finance of economic entities as the central link; others point out the national finance. In essence, these two links have different economic nature of the origin of finance and the principles of their circulation. With the gradual industrialization of economic processes, the property institute development, the formalization of its principles of existence in the world countries, the increase of an additional product at separate enterprises caused the division of management and ownership functions. Currently, a capital owner has ceased to have financial interest in the economy - only personal capital operating in the market matters. The economic mechanism of the modern mode of production is increasingly becoming complex and sensitive. Not only does increasing labour productivity increase the value of a by-product, it also increases the number of goods for sale and forms of financial relations that stimulate sales activities. For government institution the personality is not particularly important but the significant fact is the existence of tax agents and economic agents that ensure the financial inflows sustainability to replenish national funds of financial resources. In terms of commodity-cash transactions, the basis for the existence of financial flows and their subsequent redistribution are acts of sale. World trade of goods and services in 2005-2015 has the following dynamic (Table 1):

Table 1

World Trade of Goods and Services in 2005-2015, Billion USD

\begin{tabular}{|c|c|c|c|c|c|c|c|c|c|c|c|}
\hline \multirow{2}{*}{$\begin{array}{c}\text { Comparison } \\
\text { category }\end{array}$} & \multicolumn{11}{|c|}{ Years } \\
\hline & 2005 & 2006 & 2007 & 2008 & 2009 & 2010 & 2011 & 2012 & 2013 & 2014 & 2015 \\
\hline $\begin{array}{l}\text { World trade of } \\
\text { goods (1) }\end{array}$ & 10.7 & 12.3 & 14.3 & 16.2 & 12.5 & 15.4 & 18.2 & 18.6 & 19.0 & 19.2 & 16.5 \\
\hline $\begin{array}{c}\text { World trade of } \\
\text { services (2) }\end{array}$ & 2.5 & 2.7 & 3.4 & 3.8 & 3.5 & 3.7 & 4.1 & 4.3 & 4.7 & 4.9 & 4.5 \\
\hline $\begin{array}{c}\text { Excess (1) over } \\
\text { (2) }\end{array}$ & 4.28 & 4.56 & 4.21 & 4.26 & 3.57 & 4.16 & 4.44 & 4.33 & 4.04 & 3.92 & 3.67 \\
\hline
\end{tabular}

Prepared and calculated on the basis of data [2]

It has to be noted that the world trade of services (growth of 1.8 in 2005-2015) over goods (1.54 in the same period) is more active. This trend is the result of regulatory action by state and intergovernmental organizations and institutions, as well as by a market mechanism, in particular the WTO (Table 2). 
Table 2

Trade of goods by WTO member countries in 2005-2015, \%

\begin{tabular}{|c|c|c|c|c|c|c|c|}
\hline Year & $\begin{array}{c}\text { North } \\
\text { America }\end{array}$ & $\begin{array}{c}\text { South } \\
\text { America }\end{array}$ & Europe & CIS & Africa & $\begin{array}{c}\text { Middle } \\
\text { East }\end{array}$ & Asia \\
\hline 2005 & 19 & 3 & 45 & 2 & 2 & 4 & 25 \\
\hline 2006 & 18 & 3 & 45 & 2 & 3 & 5 & 24 \\
\hline 2007 & 17 & 4 & 43 & 2 & 3 & 6 & 25 \\
\hline 2008 & 16 & 5 & 42 & 3 & 3 & 6 & 25 \\
\hline 2009 & 16 & 5 & 41 & 2 & 4 & 5 & 27 \\
\hline 2010 & 16 & 6 & 39 & 2 & 4 & 6 & 27 \\
\hline 2011 & 16 & 6 & 38 & 4 & 4 & 6 & 26 \\
\hline 2012 & 17 & 6 & 37 & 5 & 4 & 7 & 24 \\
\hline 2013 & 17 & 5 & 38 & 4 & 4 & 8 & 24 \\
\hline 2014 & 18 & 5 & 39 & 3 & 4 & 7 & 24 \\
\hline 2015 & 18 & 3 & 39 & 2 & 3 & 6 & 29 \\
\hline $\begin{array}{c}\text { Exceeding } \\
2015 \text { over } \\
2005\end{array}$ & -1 & 0 & -6 & 0 & +1 & +2 & +4 \\
\hline
\end{tabular}

Prepared and calculated on the basis of data [2]

The basic law of economic development concerning the quantitative provision of conditions for extended reproduction is best fulfilled in the Asian region by the constant updating of production and other technologies; national monetary policy of Asian countries; the growth of the world economy relative to the economic growth of Asian countries; adapting to the effects of the global financial crisis. For instance, only in the period of January 2014 - March 2016 nominal effective exchange rates of individual countries had an unstable trend (in dynamics): the USA within 100-122\%, China - 100-110\%, India - 100-110\%, Japan - 100-103\%, Eurozone - 100-94\%, Brazil - 100-70\%, Russia - 100-15\%. In 2005 the economies of developed countries accounted for 55\% of exports of goods and $41 \%$ for the economies of developing countries; in 2015 this ratio changed by $43 \%$ and 52\%, respectively.

It is well known that the subject of sale and purchase in the world market are agricultural products (first group), products of the fuel industry (second group) and production (third group). The largest exporters of the first group in 2015 were the EU, the U.S., Brazil, China, Canada, Indonesia, Thailand, Australia, India and Argentina. The largest exporters of the second group in 2015 were the EU, Russia, Saudi Arabia, the USA, Australia, Canada, Qatar, the UAE, Norway and China. The largest exporters of the third group of iron and steel in 2015 were the EU, China, Japan, Korea, the USA, Russia, Brazil, Chinese Taipei, Ukraine and India. Against the background of the global dynamics of economic development, the relative performance indicators of domestic business in terms of organization are as follows (Table 3): 
Table 3

Relative Performance Indicators of Domestic Business by Organization Capacity (Extract)

\begin{tabular}{|c|c|c|c|c|c|}
\hline Year & $\begin{array}{l}\text { Big business } \\
\text { entities }\end{array}$ & $\begin{array}{c}\text { The subjects of medium- } \\
\text { sized business }\end{array}$ & $\begin{array}{l}\text { Small business } \\
\text { entities }\end{array}$ & $\begin{array}{l}\text { Subjects of micro- } \\
\text { entrepreneurship }\end{array}$ & Total \\
\hline \multicolumn{5}{|c|}{ Share of each group in the total number of economic entities, $\%$} & units \\
\hline 2010 & 0.0 & 1.0 & 99.0 & 95.9 & 2183928 \\
\hline 2011 & 0.1 & 1.2 & 98.7 & 94.5 & 1701620 \\
\hline 2012 & 0.0 & 1.3 & 98.7 & 94.4 & 1600127 \\
\hline 2013 & 0.0 & 1.1 & 98.9 & 95.1 & 1722070 \\
\hline 2014 & 0.0 & 0.9 & 99.1 & 96.3 & 1932161 \\
\hline 2015 & 0.0 & 0.8 & 99.2 & 96.8 & 1974318 \\
\hline \multicolumn{5}{|c|}{ Revenue share of economic entities, \% } & million $U A H$ \\
\hline 2010 & 39.0 & 39.3 & 21.7 & 10.3 & 3596646.4 \\
\hline 2011 & 42.3 & 38.5 & 19.2 & 8.8 & 4202455.2 \\
\hline 2012 & 39.5 & 40.0 & 20.5 & 9.8 & 4459818.8 \\
\hline 2013 & 39.6 & 38.8 & 21.6 & 10.6 & 4334453.1 \\
\hline 2014 & 39.1 & 38.9 & 22.0 & 10.9 & 4459702.2 \\
\hline 2015 & 37.0 & 39.3 & 23.7 & 12.0 & 5556540.4 \\
\hline \multicolumn{5}{|c|}{ Financial results before taxation } & million $U A H$ \\
\hline 2010 & 28471.1 & 41581.7 & -15647.1 & -13898.9 & 54405.7 \\
\hline 2011 & 92572.1 & 31090.8 & -5057.3 & -8708.3 & 118605.6 \\
\hline 2012 & 37182.2 & 47742.0 & -9254.0 & -12825.5 & 75670.2 \\
\hline 2013 & 28003.5 & 8390.1 & -25057.9 & -25038.3 & 11335.7 \\
\hline 2014 & -189934.1 & -199180.3 & -175262.4 & -100967.0 & -564377 \\
\hline 2015 & -145403.9 & -91161.8 & -111906.0 & -57964.7 & -348472 \\
\hline \multicolumn{5}{|c|}{ Net profit (loss) of enterprises } & million $U A H$ \\
\hline 2010 & 2825.0 & 30742.5 & -19661.4 & -15153.3 & 13906.1 \\
\hline 2011 & 59146.9 & 19244.6 & -10593.6 & -10542.7 & 67797.9 \\
\hline 2012 & 15203.6 & 34612.0 & -14748.3 & -14538.7 & 35067.3 \\
\hline 2013 & 8148.9 & -1567.7 & -29420.9 & -26561.4 & -22839.7 \\
\hline 2014 & -204546.2 & -206223.2 & -179297.5 & -102300.7 & -590067 \\
\hline 2015 & -152552.4 & -102769.2 & -118194.4 & -60119.0 & -373516 \\
\hline \multicolumn{5}{|c|}{ Profitability of operating activities of enterprises, $\%$} & \\
\hline 2010 & 3.9 & 5.0 & 1.8 & -3.5 & $x$ \\
\hline 2011 & 6.2 & 6.0 & 4.2 & 0.8 & $x$ \\
\hline 2012 & 5.2 & 5.0 & 4.1 & -0.1 & $x$ \\
\hline 2013 & 5.0 & 3.2 & 2.2 & -2.3 & $x$ \\
\hline 2014 & 0.7 & -3.6 & -17.9 & -30.1 & $x$ \\
\hline 2015 & 4.0 & 0.0 & -4.2 & -8.2 & $x$ \\
\hline
\end{tabular}

Based on the data of the Statistical Collection of Activities of subjects of large, medium, small and micro-enterprises, $2015[7,8]$

Apparently, resources are inefficiently used in Ukraine. In addition, domestic statistics do not capture all the results of the market economy. Private property in each country makes it impossible to prepare a plan and put an order in the economic life of society. Economically segregated businesses in the world are increasingly losing their independence by remaining legally independent. The reason for this paradox is precisely the norm of the private property 
institute: the means and objects of conducting business are privately owned and the business itself is also a private property, but their subject is not always the same person. The legal basis of the modern production method in the presence of offshore, free economic zones and other special forms and places of business - private ownership of the means of production - is becoming increasingly incompatible with the nature of the production means. On the other hand, the cost of maintaining the state apparatus increases annually in accordance with economic, political, technical and technological innovations. The costs of running a business are only matched by market demands, even globally. However, it becomes more difficult for the business owner to get an additional product in absolute terms every year because of the need for increasing investment in production, maintenance etc. There is an objective demand for services and products of the financial market, which in the early twentieth century gained worldwide recognition and distribution, but in the early 21 st century does not solve financial and economic problems in a geopolitical crisis.

World economy of the early twentieth century developed as a result of the technological revolution and the direct dominance of the US economy. This had an impact on the intensification of two business factors: productive forces and manufacturing strengths. During this period the metal-working, machine-building, metallurgy, chemical, textile and food-processing industries were actively developing. In accordance with the increase in production equipment and the growth of available labour, there was an increase in labour productivity, the number of goods produced. For 10-12 years of the second decade of the twentieth century, mechanical power in the US manufacturing industry increased by $48 \%$, available labour - by $25 \%$, the real cost of manufactured goods (at prices in 1914) - by $61 \%$, the real cost of processing - by $65 \%$. The same trend of sufficiently strong economic development has been observed in the US mining industry since the beginning of World War I. According to US economic trends, the number of businesses in Japan has increased by 3.5 times; the presence of primary establishments in them has increased by $38 \%$, and the capacity - more than 2 times. The total industry of Japanese censorship enterprises from 1913 to 1922 grew from 916 thousand people to 1691 thousand people, an increase of $85 \%$. In line with the growth of mechanical equipment and the availability of workers, the productive forces of the Japanese industry enhanced, according to which Japan's industrial output also increased. Industrial growth in Canada, Switzerland, Italy, Sweden, New Zealand, etc. was slowing down [10]. The most significant in the industrial growth of the early twentieth century was the predominant development of industries that produced means of production, which affected the level of capitalization of local economies of that time, gaining them 
financial strength of a long-term nature. Thus, the fixed capital of the German industry after the war grew at the expense of working capital. The First World War was organized by Germany at the expense of old accumulated reserves and a large amount of working capital. That was accompanied by a decrease in the purchasing power of the population. Inflation, which prompted the industry to provide liquid money, has contributed to the development of fixed capital and agriculture. The capital of the economies of the leading countries of the world at that time (the USA, Japan, Canada, Australia, Norway, Sweden, Switzerland, Italy, France, Germany, Belgium, etc.) increased by 1.5-5 times. The hiring of workers for these enterprises has only increased tactically, having acquired the highest level in 1922. The increase in the fixed capital of the industry and the permanence of the employment level at that time was opposed by the significantly reduced capacity of world markets as a result of the decline in population purchasing power. Reduction in world trade in the early twentieth century in the presence of vastly increased productive forces in industry, led to the crisis from which a number of European capitalist economies could recover after World War II.

A modern feature of economic development is the equilibrium at the international level of the institute of private ownership of some of the capital that is issued in financial instruments by their owners abroad. This is the second cause of the global crisis of capitalism, which has an ongoing projection for Ukraine. A world economic history has a well known fact. In the early twentieth century the financial collapse of France and Germany was also linked to the unsettled international financial relations, which led to a sharp decline in the liquidity of these countries' economies in the short term. The described financial and economic processes of economic prosperity and decline of individual countries are presented in accordance with the basic cycles and features of local, international and world functioning. The capitalist crisis of the early twentieth century and the geopolitical crisis of the early 21 st century have deep financial and economic foundations, to which the business responds indicatively, in particular, through bankruptcy (Table 4). 
Table 4

Statistics of the world business bankruptcies in the beginning of XX and XXI centuries (quarterly averages), units

\begin{tabular}{|c|c|c|c|c|c|c|}
\hline Country & \multicolumn{3}{|c|}{ The beginning of XX century } & \multicolumn{3}{|c|}{ The beginning of XXI century } \\
\hline & 1923 year & $\begin{array}{l}1924 \\
\text { year }\end{array}$ & 1925 year & $\begin{array}{l}2008 \\
\text { year }\end{array}$ & 2009 year & 2010 year \\
\hline \multirow[t]{3}{*}{ USA } & \multirow{3}{*}{4791} & \multirow{3}{*}{4928} & \multirow{3}{*}{4714} & 93136 & 122806 & 132756 \\
\hline & & & & $\begin{array}{l}2013 \\
\text { year }\end{array}$ & 2014 year & 2015 year \\
\hline & & & & 35500 & 28750 & 25175 \\
\hline Germany & 66 & 511 & 2780 & 2350 & 2217 & 2082 \\
\hline Italy & 1422 & $1822 *$ & 1818 & 3462 & 3888 & 3522 \\
\hline United Kingdom & 1353 & 1260 & 1254 & 3748 & 3638 & 3750 \\
\hline Sweden & 867 & 788 & 768 & 653 & 606 & 536 \\
\hline
\end{tabular}

* - indicator for 9 months in 1925

Based on data [1,3,7]

World Bankruptcy History knows a lot of examples of financial speculation, terrorist attacks, miscalculations in business processes, and natural disasters. Modern bankruptcies have two specific features: global character and currency precondition, and their quantitative indicators depend on the levels of society financial literacy and country economic development.

The modern crisis of the $21 \mathrm{st}$ century has at its core geopolitical uncertainty, the global nature of economic transformation, the streamlined vector of economic policy, the principles of public administration according to world analogues, new financial forms and rules of functioning of actors and stakeholders. Economic development of the world during the first decades of the twentieth century was determined by the policy of industrial-financial capital of the world leading countries at that time. World economic development of the $\mathrm{XXI}$ century is determined by the financial and economic results of the marketing activity as a priority in the market of services, in particular financial one. An essential factor in the success of the modern economy is the sales activity based on financial results. The main competitive advantage of this factor is the high liquidity in the absence of unified formal rules for monitoring and control of their movement within the state, interstate associations and beyond.

In 2015, the dynamics of foreign trade of goods at Ukrainian enterprises was influenced by a decrease in external demand for products due to changes in the global market conditions, as well as difficulties in sales in traditional markets (Table 5). 
Table 5

Dynamics of indicators of socio-economic development in Ukraine

\begin{tabular}{|c|c|c|c|}
\hline Indexes & $\begin{array}{c}2013 \\
\text { year }\end{array}$ & $\begin{array}{c}2014 \\
\text { year }\end{array}$ & $\begin{array}{c}2015 \\
\text { year }\end{array}$ \\
\hline $\begin{array}{c}\text { Foreign trade turnover, million USD } \\
\text { The total area of housing put into operation, } \\
\text { thousands of square meters }\end{array}$ & 140276.0 & 108295.3 & 75637.1 \\
\hline Retail turnover, million UAH & 11217.2 & 9741.3 & 11044.4 \\
\hline Retail turnover per capita, UAH & 429242.3 & 437175.0 & 344397.1 \\
\hline $\begin{array}{c}\text { Foreign direct investment in the economy } \\
\text { (hereinafter - FDI), million USD }\end{array}$ & 9449.2 & 10183.6 & 8054.1 \\
\hline FDI per capita, million USD & 1280.3 & 45916.0 & 43371.4 \\
\hline
\end{tabular}

Based on data [2]

In 2015, due to the devaluation of the national currency of Ukraine and the decrease in the value of equity capital, there was a further decline in FDI. The largest amount of foreign investment came from Cyprus, the Netherlands, Switzerland and Belgium.

Economic crisis of the XXI century by its components: the crises of the private property institute, overproduction, foreign trade, currency, banking, budgetary, financial and social ones will continue in the form of infrastructure crises. Infrastructure crisis has started in the country as a result of reduced financial awareness, access to global financial markets, and purchasing power of the population and so on. Investment attractiveness (internal and external) of Ukraine since 2013 has been continuing to decline. The issue of slowing down the economic infrastructure crisis, as noted above, is currently being addressed by a general reorientation of major trade flows. However, in Ukraine, both exports and imports tendencies have the downward trend, and the dollar component in the monetary system of the domestic economy is falling accordingly. The domestic trade surplus remains significant (US $\$-4.25$ billion in January-September 2016 versus US \$ -2.3 billion in January-September 2015, according to the balance of payments). In its relations with Ukraine, the European Union resorts to protectionism by restricting free trade by introducing quotas on the supply of products based on EU technical regulations and standards. Access to private capital markets is extremely limited, and current foreign exchange resources reduce the level of liquidity in terms of rising debt. Demand for currency to pay off corporate debt will pressure the currency market for a long time, leading to the devaluation of hryvnia and accelerating inflation. Over the last three years, the country's gross external debt has fallen by more than 21.3 billion USD including the debt of the banking sector - by 11.7 billion USD and foreign debt repayments of other commercial organizations -21.1 billion USD. At the same time, foreign debt increased by 14 billion USD. Every year, the debt burden on the budget increases with a 
sharp limitation of the mobilized funds to the budget revenue section at all levels. However, it did not stop the subjects of the international investment market to prepare an "investment pillow" for significant investments in domestic agribusiness in the near future against the backdrop of declining purchasing power of Ukrainians. All this will inevitably lead to a further exacerbation of the socio-economic contradictions that are already being signalled to the national economy.

Conclusions and prospects for further research. This tendency is cyclical, but it has new characteristics of the current financial and economic development of modern local economies of the world. It is impossible to expect that increasing the capacity of international markets in the near future will allow loading them at the expense of own demand for productive forces. This requires that the productive forces and demand of the population has to reach the level that is capable of restoring working capital in the volumes of full loading of fixed capital with a unified distribution and redistribution of the by-product.

Taking into consideration the importance of financial and economic processes in further economic development, the finances of economic entities, as generators and recipients of an additional product, take a leading position in initiating and introducing new principles of socio-economic coexistence within the state and the financial system.

\section{References}

1. Artemieva E. Statistical analysis of Bankruptcy in the United States [Electronic resource] / E. Artemieva // Proceedings of the IV International Student Electronic Scientific Conference "Student Scientific Forum" (Moscow, February 15 - March 31, 2012) - Access mode: http://www.rae.ru/forum2012/pdf/0270.pdf.

2. Credit Rating Renewal Rating Report (NKLV 005-018) - Mykolaiv city / Credit rating agency. $-2016-50 \mathrm{p}$.

3. Dun \& Bradstreet (2016). Global Bankruptcy Report 2016. Retrieved from: https://www.dnb.ru/en/news/bankruptcy/.

4. James Rickards. The death of money. The coming collapse of the international global system. New York. 2014. 356 p.

5. Marshall John F. Financial Engineering: A Complete Guide to Financial Innovation: A Textbook / D.F. Marshall, V.K. Bansal. - M.: INFRA-M, 1998. - 784 p.

6. Melnychuk L. The policy of social equalization of regional development: European standards / L. Melnychuk // Journal of Investments: Practice and Experience. - No. 16/2015. - pp. 112-116. 
7. Official site of the State Statistics Service of Ukraine [Electronic resource]. Access mode: http://www.ukrstat.gov.ua/.

8. Piketti T. Capital in the 21st Century [Electronic resource] / T. Piketty. - Access mode: https://coollib.com/b/331388.

9. Public Policy and Management: research / [ed. : S. Teleshun, O. Titarenko, S, Sytnik, S. Virovyi]. - K.: NADU, 2010. - 36 p.

10. World Economy Statistics / [ed. S. Umansky]. - M.: Central Statistical Office of the USSR: Department of Foreign Statistics. M.K.H.'s typography named after F.Ya. Lavrova, 1926. - Issue. 2-3. - 197 p.

11. World trade statistical review 2016 (2016). World Trade Organization. Retrieved from: https://www.wto.org/english/res_e/statis_e/wts2016_e/wts16_toc_e.htm. 